\title{
Relationships between digestibility and cell wall structure of forage maize
}

\author{
JM Besle 1, V Serre 1, MP Maillot 1, J Andrieu 1, C Demarquilly 1, Y Barrière 2 \\ IINRA, Unité Digestion Microbienne, Theix, 63122 St-Genès-Champanelle; \\ 2INRA, SAPF, 86600 Lusignan, France
}

The relationships between lignin content and digestibility are widely documented. However the study of cell wall phenylpropanoids components may both explain the mechanisms limiting degradation and help to predict the digestibility of forages, in particular in varieties at a similar growth stage (Jung and Vogel, 1992, J Sci Food Agric, 59, 169-176). These relationships were studied in maize whole crop.

Whole plants of normal maize were collected at six stages after flowering ( 1 variety) and at silage stage ( 7 varieties). All but two varieties, which were given as silages, were fed fresh to sheep. Digestibility was measured on diet given at about $45 \mathrm{~g} / \mathrm{kg} W^{0.75}$ during six days. Starch was analysed (Thivend et al, 1965, Ann Bioch Anim Biophys, 18, 237-247) and removed. After solvent extraction, the resulting cell wall residues (CWRs) were analysed for lignin, (Jarrige, 1961, Ann Biol Anim Biophys, 1, 163-212), esterified phenolic acids ( $p$-coumaric acid, PCA) and lignin uncondensed monomers (nitrobenzen oxidation products, $\mathrm{NBO}: \mathrm{p}-\mathrm{OH}$ benzaldehyde ' $\mathrm{B}$ ', vanillin ' $\mathrm{V}$ ', syringaldehyde ' $\mathrm{S}$ ') (Mosoni et al, 1993, J Agr Food Chem, 1349-1354). NDF was analysed in diet and faeces (Goering and Van Soest, 1970, J Agr Handbook 379, USDA).

With increasing maturity, organic matter digestibility (OMD) increased (range 0.72 0.77 ), following the starch content, whereas NDF digestibility (NDFD, range 0.60-0.68) did not decrease. The CWRs decreased (from 677 to about $500 \mathrm{mg} / \mathrm{g} \mathrm{DM}$ ) in parallel with the increase of starch content (from 53 to 333 $\mathrm{mg} / \mathrm{g}$ DM). In the CWRs, only lignin content (decrease from 136 to $116 \mathrm{mg} / \mathrm{g}$ CWR) was related with age.
Within plants at silage stage the ranges of OMD and of NDFD were 0.68-0.76 and $0.51-0.62$, respectively. The range of NDF was $428-502 \mathrm{mg} / \mathrm{g} D M$; the ranges of lignin content (103-146 mg/g CWR) and of other components were greater than across maturity stage.

Several constituents were highly correlated $(P<0.05)$ across maturity stages with OMD (lignin \% DM, R $=-0.96 ; P C A \% D M$, $R=0.80 ; N B O \%$ lignin, $R=0.80 ; B \%$ lignin, $\mathrm{R}=0.79$ ) but the relationships were lower within varieties. The reverse trend was observed for NDFD. Significant relationships were only observed within varieties, lignin was less associated with NDFD $(R=-0.70)$ than p-coumaric acid $(R=0.89)$ and some NBO products ( $B \%$ lignin, $R=0.81 ; S N, R=0.89$ ). $S$ and NBO proportions in lignin and ferulic acid to PCA ratio also were fairly good predictors.

PCA and S/ are associated with lignin content but, since they are mainly found in the secondary wall, they probably characterize the accessibility of the secondary wall. Some data are in agreement with previous studies but several variations were different from those observed in vegetative part of growing plant or in prairie grasses (Reeves, 1987, J Dairy Sci, $70,1583-1594)$. The discrepancies are probably caused by the heterogeneity and complexity of whole maize, but the phenylpropanoid components can be utilized to predict the variability in digestibility.

Acknowledgements : This work was supported by a grant from Limagrain Genetics International, BP1, 63720, Chappes, France. 